\title{
EFEKTIVITAS PENDEKATAN SUPERVISI PENGAJARAN NON-DIREKTIF \\ PENGAWAS AGAMA HINDU
}

\section{Studi Pada Gugus Kelusa Kec. Payangan, Kab. Gianyar Tahun Pelajaran 2013/2014}

\author{
Oleh: \\ Ida Bagus Nyoman Rai Wiyadnyana \\ Kementrian Agama Kabupaten Gianyar, Jln. Kepundung 8, Gianyar \\ ibn_raiwiyadnyana@gmail.com
}

\begin{abstract}
The implementation of the non-directive learning supervision is very representative in enhancing the ability of the teachers of Hinduism to serve PAIKEM learning within the elementary schools that belong to the Klusa group in the district of Payangan, Gianyar, due to: First, there is also an increase of the teachers' competence in developing the learning scenarios.

Second, the percentage of teachers' ability in presenting the PAIKEM learning is also increasing significantly by $84 \%$ which is in the pre-cycle only reaches $16 \%$ or only 1 teacher is considered in the good category. On the first cycle it is of $66 \%$ that means there are 4 teachers who are in the good category and on the the second cycle the percentage reaches $100 \%$ or all the teachers, the research subjects, has been able to complete the PAIKEM learning.

Thus, this study has been finished on the second cycle because conceptually the research indicators have been achieved. In general, the implementation levels of the non-directive learning supervision have already been performed according to the plan.
\end{abstract}

\section{Abstrak}

Pelaksanaan supervisi pembelajaran non-direktif sangat representative dalam meningkatkan kemampuan guru menyajikan pemelajaran PAIKEM pada guru agama Hindu tingkat SD gugus Klusa Kecamatan Payangan, Kabupaten Gianyar karena: Pertama, terjadi pula peningkatan kompetensi guru dalam menyusun skenario pembelajaran.

Kedua, persentase kemampuan guru dalam menyajikan pembelajaran PAIKEM juga mengalami peningkatan signifikan, yaitu sebesar $84 \%$ yaitu pada pra-siklus mencapai $16 \%$ atau hanya 1 guru dalam kategori baik, siklus I 66\% yaitu ada 4 orang guru yang berada dalam kategori baik serta pada siklus II persentase mencapai $100 \%$ atau dengan kata lain semua guru yang menjadi subjek penelitian telah mampu menyusun pembelajaran PAIKEM.

Jadi, penelitian ini dicukupkan pada siklus II sebab secara konseptual indikator kerja penelitian telah tercapai. Secara umum tahapan-tahapan pelaksanaan supervisi pembelajaran non-direktif yang dilakukan sudah sesuai dengan rencana.

Kata kunci: Supervisi Non Direktif, Kemampuan Guru, Pembelajaran PAIKEM 


\section{PENDAHULUAN}

\subsection{Latar Belakang Masalah}

Peran serta pengawas sebagai salah satu stake holder sekolah, mutlak diperlukan, hal ini disebabkan karena pengawas merupakan tempat atau wadah bagi guru untuk menyampaikan keluh kesah terkait permasalahan yang dihadapi khususnya yang berkaitan dengan proses transformasi pengetahuan. Dari kondisi tersebut diatas tentunya untuk mendapatkan solusi perlu diupayakan berbagai hal, dalam kapasitas peneliti yang merupakan pengawas agama Hindu, tingkat sekolah dasar, kegiatan supervisi dipandang refresentatif dijadikan landasan guna mencari pemecahan terkait upaya menumbuhkan minat dan motivasi siswa dalam belajar agama Hindu yang tentunya bermuara pada upaya meningkatkan kemampuan guru dalam menyajikan pembelajaran yang aktif, efektif, inovatif dan menyenangkan.

Salah satu upaya pengawas dalam memberikan solusi terkait dengan permasalahn yang dihadapi guru adalah melalui pendekatan supervisi pengajaran. Hal ini dimaksudkan mengingat esensi dari supervisi yang sangat berkaitan dengan berbagai prosedur dan langkah-langkah, teknik-teknik, instrumen-instrumen, kondisi-kondisi interaksi sosial antara kepala sekolah dan guru, permasalahan yang dihadapi oleh guru, tingkat kematangan guru, serta tujuannya, maupun dampak dan kemanfaatan dari masingmasing pendekatan supervisi pengajaran tersebut akan memiliki keunggulan dan kekurangannya.

Mengacu pada psikologi humanistik yang didasarkan pada pemikiran bahwa belajar adalah hasil keingintahuan individu untuk menemukan rasionalitas dan keteraturan di alam ini, sehingga belajar dipandang sebagai proses pembawaan yang berkembang (terbuka). Guru menunjang keingintahuan individu dan hasil belajar melalui self-discovery. Sehingga berdasarkan psikologi humanistik, bahwa pendekatan yang cocok untuk supervisi adalah pendekatan nondirektif.

Supervisi non-direktif berasumsi bahwa belajar pada dasarnya adalah pengalaman pribadi dimana individu pada akhirnya harus menemukan pemecahan masalah sendiri untuk memperbaiki pengalaman murid di dalam kelas. Peran supervisor adalah mendengarkan, tidak memberikan pertimbangan, membangkitkan kesadaran sendiri, dan mengklarifikasikan pengalaman guru (Glickman, 1990: 210). Pendekatan non-direktif ini timbul dari keyakinan bahwa guru tersebut tidak dapat diperlakukan sebagai alat semata-mata dalam meningkatkan kualitas belajar-mengajar. Dalam proses pembinaan, guru mengalami perkembangan secara terus menerus, sehingga program supervisi harus dirancang untuk mengikuti perkembangan guru.

Bertolak dari latar belakang masalah tersebut di atas, maka masalah pokok yang ingin dicari solusi melalui penelitian ini: Apakah pelaksanaan pendekatan supervisi pengajaran non-direktif efektif dalam meningkatka kompotensi guru agama hindu dalam menyajikan pembelajaran aktif inovatif efektif dan menyenangkan (Paikem) pada Gugus Kelusa Kecamatan Payangan Kabupaten Gianyar Tahun Pelajaran 2013/2014?

Fokus perbaikan yang dilakukan dalam penelitian ini adalah meningkatkan kualitas pembelajaran di kelas yang lebih menarik, lebih efektif dan menyenangkan bagi siswa melalui penerapan supervisi non direktif. Pendekatan non-direktif ini timbul dari keyakinan bahwa guru tersebut tidak dapat diperlakukan sebagai alat semata-mata dalam meningkatkan kualitas belajar-mengajar.

Dalam proses pembinaan, guru mengalami perkembangan secara terus menerus, sehingga program supervisi harus dirancang untuk mengikuti perkembangan. Tugas supervisor adalah membimbing guru-guru sehingga makin lama guru makin dapat berdiri sendiri dan berkembang dalam jabatan dengan usaha sendiri.

Secara umum penelitian ini bertujuan untuk mendeskripsikan tingkat kecenderungan kualitas pembelajaran inovatif guru dan menganalisis pelaksanaan supervisi pengajaran non-direktif dalam upaya meningkatkan kompotensi guru dalam menyajikan pembelajaran inovatif guru SD di Kecamatan Payangan Gianyar. Sedangkan manfaat yang dapat dipetik dari hasil penelitian ini secara umum adalah memberikan sumbangan pemikiran kepada pengambil kebijakan khususnya Pemerintah Kabupaten Gianyar melalui Kementrian Agama Kabupaten Gianyar dalam rangka meningkatkan kualitas manajemen pembelajaran inovatif guru sehingga nantinya kualitas sumber daya manusia mampu 
bersaing di era global.

\subsection{Metode Penelitian}

Penelitian yang dilakukan termasuk jenis penelitian tindakan. Penelitian tindakan ini terfokus pada penelitian tindakan sekolah. Penelitian ini dilaksanakan di Gugus Kelusa SD di Kecamatan Payangan berjumlah 5 (lima sekolah). Sedangkan yang menjadi subjek penelitian adalah guru Agama Hindu SD Gugus Kelusa di Kecamatan Payangan. Oleh karena itu penelitian ini melibatkan guru sebanyak 6 orang yang dijadikan subjek penelitian. Yang menjadi objek penelitian ini adalah proses pelaksanaan supervisi non direktif dan peningkatan kemampuan guru dalam menyajikan pembelajaran pembelajaran aktif, inovatif, efektif dan menyenangkan khususnya model pembelajaran berbasis masalah, dalam mata pelajaran Agama Hindu.

Penelitian ini dilaksanakan di Gugus Kelusa SD di Kecamatan Payangan yang berjumlah 5 (lima sekolah). Penelitian ini dilakukan selama 3 bulan mulai bulan agustus sampai bulan Oktober 2013. Kegiatannya masing-masing siklus termasuk perencanaan/ pembuatan proposal, pelaksanaan, pengamatan dan refleksi. Untuk menyajikan analis hasil tindakan dilakukan dengan beberapa cara yaitu: content analisis, diskripsi prosentase, tabel dan grafik. Content analis (Hujair AH Sanaky, 2002: 29) digunakan untuk membuat kesimpulan setelah peneliti melakukan kajian secara mendalam. Diskripsi verbal untuk menguraikan pelaksanaan tindakan, prosentse tingkat profesionalistas guru. Tabel digunakan untuk menyajikan hasil tindakan berupa progres profesionalistas guru siklus pertama, kedua dan seterusnya. Grafik digunakan untuk menunjukan perbandingan tingkat keberhasilan tindakan siklus pertama dan kedua.

Data yang diperoleh dianalisis dengan menggunakan analisis kualitatif dan kuantittaif. Analis kuantitatif untuk menunjukan skor perolehan setiap guru. Dan analis kualitatif untuk menujukan tingkat profesionalitas guru yang ditunjukan dengan nilai A: 85-100 (Baik Sekali) B: 71-84 (Baik) C: 56-70 (Cukup) D: < 56 (kurang). Prosedur pada penelitian ini dilakukan dalam dua siklus dan masing-masing siklus terdiri atas: perencanaan, pelaksanaan, observasi dan refleksi.

Indikator Kerja dari penelitian ini adalah Se- kurang-kurangnya 75\% guru agama Hindu pada gugus Gugus Kelusa Kecamatan Payangan, Kabupaten Gianyar memenuhi kriteria sesuai dengan instrumen supervisi akademik terutama dalam menyajikan pembelajaran yang aktif, inovatif efektif dan menyenangkan (nilai rata-rata 400-5,00 dalam skala 1-5).

\subsection{Kerangka Berpikir}

Berdasarkan pada uraian dan kajian teoritik dan empirik seperti yang telah diuraikan di atas, maka yang menjadi konsentrasi penelitian ini adalah berfokus pada persoalan-persoalan yang berkaitan dengan bagaimana program kegiatan supervisi pengajaran non - direktif para kepala sekolah terutama dilihat dari sisi implementasi pendekatan, lebih jauh bagaimana implementasi pendekatan supervisi pengajaran tersebut berpengaruh terhadap kualitas pengembangan model pembelajaran inovatif yang dilakukan oleh seorang guru.

Supervisi non-direktif berasumsi bahwa belajar pada dasarnya adalah pengalaman pribadi dimana individu pada akhirnya harus menemukan pemecahan masalah sendiri untuk memperbaiki pengalaman murid di dalam kelas. Peran supervisor adalah mendengarkan, tidak memberikan pertimbangan, membangkitan kesadaran sendiri, dan mengklarifikasikan pengalaman guru. Pendekatan non-direktif ini timbul dari keyakinan bahwa guru tersebut tidak dapat diperlakukan sebagai alat semata-mata dalam meningkatkan kualitas belajar mengajar.

Dalam proses pembinaan, guru mengalami perkembangan secara terus menerus dan alami, sehingga program supervisi harus dirancang untuk mengikuti perkembangannya. Belajar dilakukan melalui pemahaman tentang pengalaman nyata yang dialami secara riil. Dengan demikian guru dapat mencari sendiri pengalaman itu secara aktif.

Dorongan dari luar diri yang bersifat fisiologis yang kemudian secara berangsur-angsur berubah menjadi dorongan yang bersifat dari dalam atau internal, yaitu karena guru-guru merasa bahwa belajar merupakan kewajiban yang harus dilakukan dalam tugasnya. Pada konsep ini guru diyakini mampu melakukan analisis dan memecahkan masalah yang dihadapinya dalam tugas mengajarnya secara alami. Guru merasakan adanya kebutuhan bahwa ia harus berkembang dan mengalami perubahan, dan ia 
bersedia mengambil tanggung jawab terjadinya dalam perubahan tersebut.

Supervisor hanya befungsi sebagai fasilitator dengan menggunakan struktur formal sekecil mungkin. Dengan demikian dapat diduga bahwa pendekatan supervisi pengajaran non-direktif dapat meningkatkan kemampuan guru dalam mengembangkan pembelajaran inovatif.

\subsection{Hipotesis Tindakan}

Pendekatan supervisi pengajaran non-direktif oleh pengawas agama Hindu Tingkat SD efektif meningkatkan kompetensi guru agama hindu dalam menyajikan pembelajaran aktif inovatif efektif dan menyenangkan (Paikem) pada Gugus Kelusa Kecamatan Payangan Kabupaten Gianyar Tahun Pelajaran 2013/2014

\section{PEMBAHASAN}

\subsection{Supervisi Pengajaran Non-Direktif}

Supervisi non-direktif berasumsi bahwa belajar pada dasarnya adalah pengalaman pribadi dimana individu pada akhirnya harus menemukan pemecahan masalah sendiri untuk memperbaiki pengalaman murid di dalam kelas. Peran supervisor adalah mendengarkan, tidak memberikan pertimbangan, membangkitkan kesadaran sendiri, dan mengklarifikasikan pengalaman guru (Glickman, 1990). Supervisi nondirektif ini oleh Soetjipto dan Raflis Kosasi (1999) disebut juga dengan nama pendekatan humanistik. Pendekatan non-direktif ini timbul dari keyakinan bahwa guru tersebut tidak dapat diperlakukan sebagai alat semata-mata dalam meningkatkan kualitas belajar-mengajar. Dalam proses pembinaan, guru mengalami perkembangan secara terus menerus, sehingga program supervisi harus dirancang untuk mengikuti perkembangannya.

Tugas supervisor adalah membimbing guruguru sehingga makin lama guru makin dapat berdiri sendiri dan berkembang dalam jabatannya dengan usaha sendiri. Belajar dilakukan melalui pemahaman tentang pengalaman nyata yang dialami secara riil. Dengan demikian guru harus mencari sendiri pengalaman itu secara aktif. Dorongan dapat berasal dari yang bersifat fisiologis yang kemudian secara berangsurangsur berubah menjadi dorongan yang bersifat dari dalam atau internal, yaitu karena guru-guru merasa bahwa belajar merupakan kewajiban yang harus dilakukan dalam tugasnya. Supervisor percaya bahwa guru mampu melakukan analisis dan memecahkan masalah yang dihadapinya dalam tugas mengajarnya. Guru merasakan adanya kebutuhan bahwa ia harus berkembang dan mengalami perubahan, dan ia bersedia mengambil tanggung jawab terjadinya dalam perubahan tersebut. Supervisor hanya berfungsi sebagai fasilitator dengan menggunakan struktur formal sekecil mungkin.

Supervisor menggunakan pendekatan ini dalam melaksanakan supervisi tidak dituntut untuk menggunakan format yang standar, tetapi agar disesuaikan dengan kebutuhan guru. Bisa jadi kegiatan supervisi tersebut hanya terbatas melakukan observasi saja tanpa dilanjutkan dengan melakukan analisis dan interpretasi, atau bisa jadi hanya melakukan komunikasi yang berupa mendengar penjelasan guru tanpa memberi sumber bahan belajar yang diminta guru. Walaupun secara umum dapat disebutkan bahwa pelaksanaan supervisi pengajaran dengan pendekatan non direktif tersebut ada tiga langkah, tetapi secara lebih teknis dapat dirinci sebagai tersebut di bawah ini.

1) Pembicaraan awal, pada saat ini supervisor memancing apakah dalam mengajarnya guru tersebut mengalami masalah. Pembicaraan tersebut

dilakukan secara informal. Jika dalam pembicaraan tersebut guru tidak memerlukan bantuan, maka proses supervisi berhenti.

2) Observasi. Jika guru perlu, maka supervisor mengadakan observasi kelas. Dalam melaksanakan observasi tersebut supervisor duduk di belakang tanpa menggunakan catatancatatan, supervisor hanya mengamati kegiatan kelas.

3) Analisis dan interpretasi. Setelah observasi dilakukan, supervisor kembali ke kantor memikirkan kemungkinan kekeliruan guru dalam melaksanakan proses belajarnya. Jika menurut supervisor, guru telah menemukan jawabannya maka supervisor tidak perlu memberikan bantuannya. Apabila diminta oleh guru, supervisor hanya menjelaskan dan melukiskan keadaan kelas tanpa dilengkapi dengan penilaian. Supervisor kemudian menanyakan kepada guru apakah memerlukan saran, dan memberikan kesempatan untuk mencoba cara lain yang diperkirakan oleh guru lebih baik. 
4) Pembicaraan akhir. Jika perbaikan telah dilakukan, pada periode tertentu guru dan supervisor mengadakan pembicaraan akhir, mengenai apa yang sudah dicapai oleh guru, dan menjawab pertanyaan kalau ada guru yang masih memerlukan bantuan lagi.

5) Laporan, laporan disampaikan secara deskriptif dengan interpretasi berdasarkan penilaian supervisor. Laporan ini ditulis untuk guru, kepala sekolah, atau atasan kepala sekolah untuk perbaikan di masa selanjutnya. Berdasarkan beberapa pendekatan supervisi pengajaran yang telah diuraikan di atas, maka pendekatan pengajaran yang difokuskan dalam penelitian ini adalah pendekatan supervisi pengajaran non-direktif. Hal ini disebabkan karena pendekatan-pendekatan yang lainnya sudah sering dilakukan. Di samping alasan tersebut juga didasarkan bahwa pada umumnya guru tidak dapat diperlakukan sebagai alat semata-mata dalam meningkatkan kualitas manajemen pembelajaran inovatif. Dalam proses pembinaan, guru mengalami perkembangan secara terus menerus, sehingga program supervisi harus dirancang untuk mengikuti perkembangannya (Soetjipto dan Raflis Kosasi, 1999).

\subsection{Kompotensi Guru}

Kompetensi menurut Direktorat Pembinaan Sekolah Menengah Atas (Perangkat Penilaian KTSP, 2007: 39), adalah kemampuan yang meliputi pengatahuan, ketrampilan, sikap dan nilainilai yang diwujudkan melalui kebiasaan berpikir dan bertindak. Setiap guru dituntut memiliki empat kompetensi, seperti diatur dalam Peraturan Menteri Pendidikan Nasional No.16 tahun 2007 meliputi:

a. Kompetensi pedagogik;

b. Kompetensi kepribadian;

c. Kompetensi profesional; dan

d. Kompetensi sosial.

Kompetensi pedagogik terkait dengan kemampuan dan komitmen guru dalam merancang pembelajaran, melaksanakan pembelajaran, mengevaluasi, melaksanakan analisis hasil evaluasi serta melaksanakan program remidial dan pengayaan. Kompetensi meliputi ranah kognitif, psikomotor dan afektif. Dalam penelitian kompotensi yang dimaksudkan adalah kemampuan guru dalam menyajikan pembelajaran yang inovatiif, ketrampilan guru dalam mengaplikasikan pembelajaran yang menyenangkan ba- gi siswa dan komitmen guru dalam menyajikan pembelajaran dengan strategi PAIKEM.

\subsection{Pembelajaran Aktif Inovatif Efektif dan Menyenangkan (PAIKEM)}

'Menurut Soekamto (1997: 78) model pembelajaran merupakan kerangka konseptual yang melukiskan prosedur sistematis dalam mengorganisasikan pengalaman belajar untuk mencapai tujuan belajar tertentu, dan berfungsi sebagai pedoman bagi para perancang pembelajaran dan para pengajar dalam melaksanakan aktivitas belajar mengajar. Joyce dan Well (1992: 4) mengatakan bahwa suatu model pembelajaran adalah suatu perencanaan atau suatu pola yang digunakan sebagai pedoman dalam merencanakan pembelajaran di kelas. Lebih lanjut dijelaskan bahwa model pembelajaran mengarahkan guru dalam mendesain pembelajaran untuk membantu peserta didik mencapai tujuan pembelajaran. Dengan demikian, model pembelajaran merupakan rencana dan upaya sistematis yang dilakukan guru untuk membantu siswa mencapai tujuan pembelajaran.

Dalam dunia kepustakaan dikenal ada beberapa model pembelajaran inovatif, mulai dan model reasoning and problem solving, model inquiry training, model problem-based instruction, model investigation, model kooperatif MURDER, model kooperatif STAD, model kooperatif TAI, model kooperatif Jigsaw, model kooperatif pembelajaran berbasis proyek, dan model pembelajaran beorientasi Nature of Science (NO).

Terdapat lima unsur dasar dalam model pembelajaran inovatif (Joice dan Well, 1980), yaitu: (1) syntax adalah langkah-langkah operasional pembelajaran, (2) social system adalah suasana norma yang berlaku dalam pembelajaran, (3) principles of reaction adalah menggambarkan bagaimana seharusnya guru memandang, memperlakukan, dan merespon siswa, (4) support system, segala sarana, bahan, alat, atau lingkungan belajar yang mendukung pembelajaran, dan (5) instructional dan nurturant effect adalah berupa hasil belajar yang diperoleh langsung berdasarkan tujuan yang disasar dan hasil belajar di luar sasaran.

\subsection{Hasil Penelitian}

Secara umum tahapan-tahapan pelaksanaan supervisi pembelajaran non- direktif yang dilakukan sudah sesuai dengan rencana. Hasil ob- 
servasi yang dilakukan terhadap pelaksanaan supervisi yang dilakukan tampak bahwa dari empat belas indikator yang digunakan sebagai acuan mengobservasi pelaksanaan supervisi pembelajaran non-direktif, tampak bahwa semuanya (sudah dijalankan dengan baik)

Adapun data atau hasil yang diperoleh selama penelitian akan diuraikan pada pembahasan di bawah ini:

Tabel 2.3

Rekapitulasi Peningkatan Kemampuan Guru dalam menyajikan pembelajaran Paikem Melalui implementasi supervisi Non Direktif selama pelaksanaan Tindakan

\begin{tabular}{|c|l|c|c|c|c|}
\hline No & \multicolumn{1}{|c|}{ Uraian } & $\begin{array}{c}\text { Kondisi } \\
\text { Awal }\end{array}$ & Siklus I & Siklus II & $\begin{array}{c}\text { Total } \\
\text { Peningkatan }\end{array}$ \\
\hline 1 & $\begin{array}{l}\text { Rata-rata kemampuan guru terhadap 14 } \\
\text { aspek penilain KBM }\end{array}$ & 1,54 & 2,63 & 3,14 & 1,60 \\
\hline 2 & Rata-Rata Nilai Skenario Pembelajaran & 63,33 & 78,33 & 84,17 & 20,84 \\
\hline 3 & $\begin{array}{l}\text { Prosentase Kompotensi Guruyang mampu } \\
\text { Menyajikan pembelajaran PAIKEM }\end{array}$ & $16 \%$ & $66 \%$ & $100 \%$ & $84 \%$ \\
\hline
\end{tabular}

Grafik. I

Grafik Histogram Rata-Rata Kemampuan Guru Agama Hindu Gugus Klusa, Payangan ,Terhadap 14 Aspek Penilain KBM, Selama Tindakan

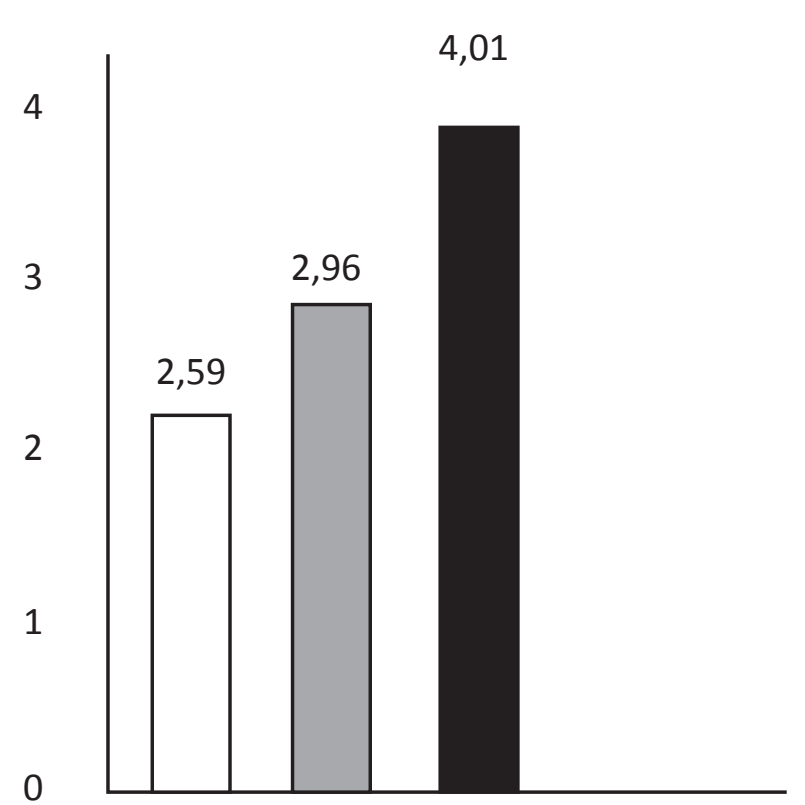

Keterangan Gambar:

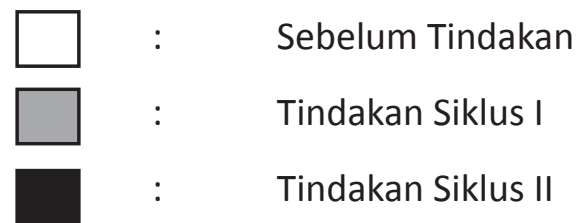

Grafik. II

Histogram Rata-Rata Nilai Skenario Pembelajaran Sesuai dengan Pedoman Supervisi, dan observasi kelas.

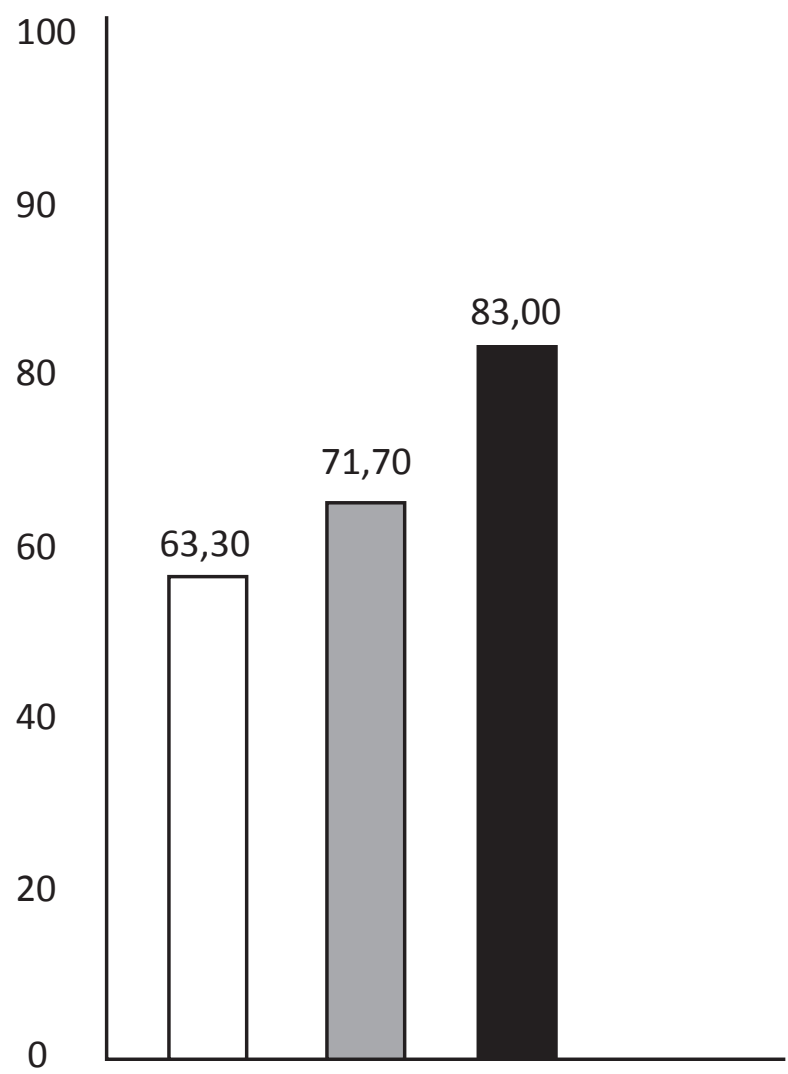

Keterangan Gambar:

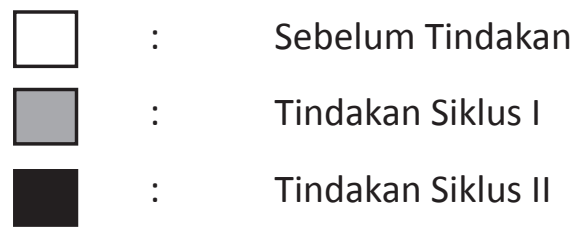


Grafik. III.

Histogram Persentase Peningkatan Kemampuan Menyajikan Pembelajaran Paikem melalui Supervisi Non Direktif.

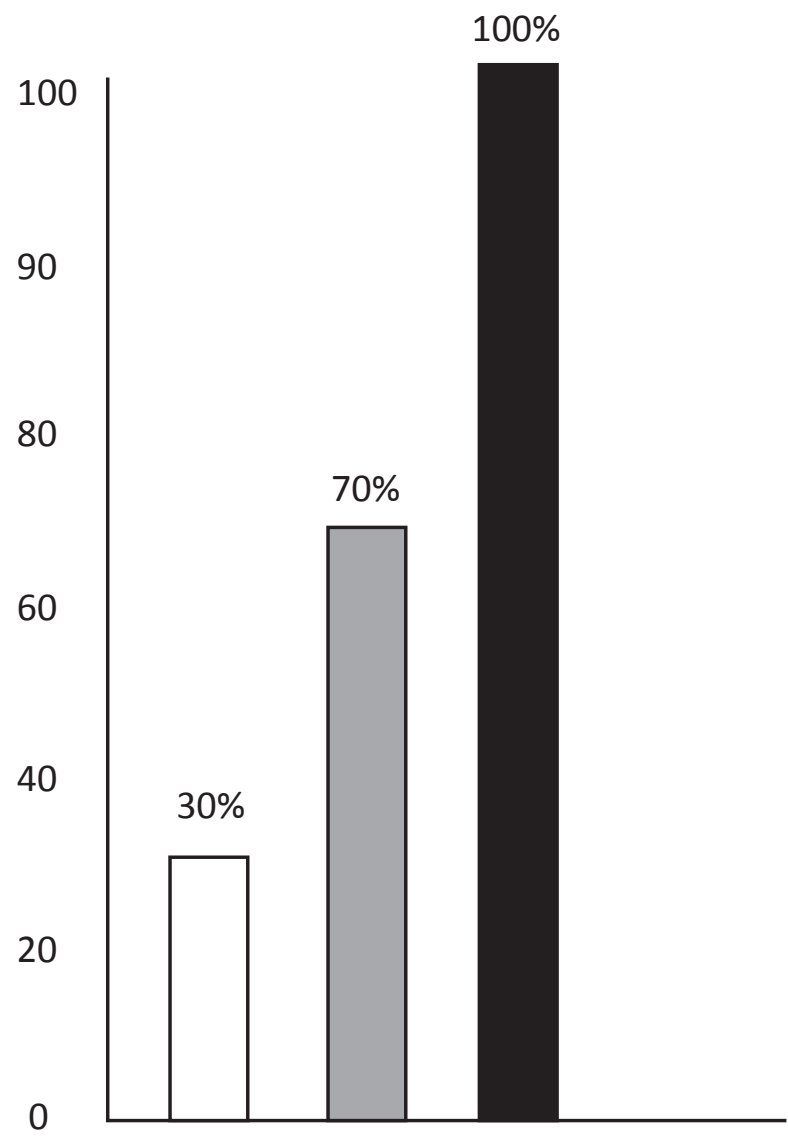

Keterangan Gambar:

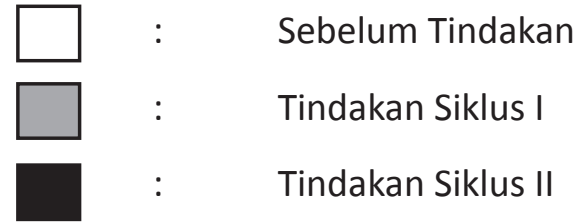

Berdasarkan hasil analisa aktivitas guru dalam menyusun skenario pembelajaran dan dalam pengelolaan kelas berdasarkan hasil observasi siklus satu sampai siklus II terjadi peningkatan yang signifikan. Berdasarkan pada lampiran 4.1 dan 4.3 nilai rata-rata kemampuan guru terhadap 14 aspek yang dinilai terjadi peningkatan dari pra siklus ke siklus II sebesar 1, 60 , yaitu pada pra siklus rata-rata 1,54 pada siklus I meningkat menjadi 2,53 dan pada siklus II menjadi 3,14 dalam penilaian sklaa 1-5.

Selain itu terjadi pula peningkatan kompetensi guru dalam menyusun skario pembelajaran yakni yang semula pada pra siklus dengan rata-rata 63,33 dalam kategori kurang, pada siklus I hasilnya 78, 83 termasuk katagori "cukup" dan pada siklus II mengalami peningkatan menjadi 84,17 atau dengan kategori amat Baik. Prosentase kemampuan guru dalam menyajikan pembelajaran PAIKEM juga mengalami peningkatan yang signifikan, yaitu sebesar 84\% yaitu pada prasiklus mencapai $16 \%$ atau hanya 1 guru yang ada dalam kategori baik, siklus I $66 \%$ yaitu ada 4 orang guru yang berada dalam kategori baik serta pada siklus II prosentase mencapai $100 \%$ atau dengan kata lain semua guru yang menjadi subjek penelitian telah mampu menyusun pembelajaran PAIKEM. Sehingga dengan demikian penelitian ini dicukupkan pada siklus II sebab secara konseptual indikator kerja penelitian telah tercapai.

Kualifikasi pelaksanaan supervisi pembelajaran non-direktif tergolong baik. Hal ini terjadi karena supervisor memahami konsep dasar supervisi non-direktif. Dalam kaitannya dengan supervisi, kualitas supervisi pembelajaran yang diberikan oleh supervisor kepada guru, penciptaan iklim belajar, memberikan motivasi dan reward/reinforcement, memegang peran sangat penting dalam upaya meningkatkan performance dan kemampuan guru dalam menggunakan model-model pembelajaran. Dengan memberikan layanan yang berkualitas sesuai dengan standar yang telah ditetapkan, bahkan melampaui dari apa yang diharapankan (exceed expectations) akan dapat memuaskan stakeholders bidang pendidikan.

Keterampilan yang perlu dimiliki oleh supervisor adalah keterampilan manusiawi (human skills). Sebagaimana kita ketahui bahwa manusia adalah sumber daya organisasi yang paling penting. Efisiensi organisasi dan tingkat pencapaian tujuan-tujuan adalah sebuah fungsi dari dimensi manusiawi. Aspek manusia dalam organisasi merupakan hal yang paling kompleks. Perbedaan mereka sangat banyak baik di dalam aspek fisik, emosional, maupun di dalam kemampuan konseptual. Kecakapan manusiawi merupakan kemampuan untuk bekerja secara efektif di dalam sebuah kelompok dan membangun kerja sama di antara para anggota kelompok. Kecakapan ini juga meliputi kemampuan untuk membangkitkan semangat dan mempengaruhi orang lain untuk bekerja sama dan untuk mengembangkan tim kerja efektif untuk menerima perubahan. Kecakapan ini ditunjukkan di dalam persepsi dan perilaku supervisor dalam berhubungan baik dengan atasan maupun bawa- 
han yang dibimbingnya.

Untuk mencapai kesepakatan terhadap tujuan-tujuan, seorang supervisor yang cakap akan memecah pernyataan-pernyataan tujuan yang komprehensif ke dalam tujuan-tujuan yang mempunyai makna bagi satu tingkat atau disiplin tertentu. Kecakapan ini membutuhkan: pertama, pemahaman terhadap sifat dari tujuan-tujuan, kedua, kemampuan untuk menterjemahkan ke dalam sub bagian-sub bagian yang bermakna, dan ketiga, pengetahuan mengenai para guru dan nilai-nilai yang mereka anut.

Menyelenggarakan diskusi kelompok (conducting group discussion). Supervisor pembelajaran sering berada dalam posisi sebagai ketua sebuah kelompok. Sebagai ketua kelompok supervisor harus mampu melaksanakan diskusi kelompok. Kecakapan ini meliputi: pengaturan acara, mengajukan pertanyaan yang melancarkan diskusi, menjelaskan apa yang dimaksud, membangkitkan semangat atau mendorong para peserta yang malas, menjaga agar kelompok tetap pada pokok semula, menjadi juri dalam pengambilan suara, dan membuat ringkasan mengenai rekomendasi dan kesimpulan. Oleh karena begitu banyak pekerjaan dalam organisasi dapat dicapai melalui studi dan kerja kelompok, maka penting sekali supervisor menjadi pemimpin kelompok yang efektif.

Dalam supervisi non direktif ini peran supervisor tidak banyak, hanya mengarahkan guru memahami dan memecahkan masalahnya sendiri. Dalam orientasi tidak langsung ini guru bertindak sebagai penentu utama (ultimate determinant) tentang tindakan-tindakan yang akan dilakukan pada masa yang akan datang. Gurulah yang harus merencanakan segala sesuatunya yang berhubungan dengan apa yang akan dilakukan. Dengan demikian guru paling tahu kebutuhannya, sehingga dapat meningkatkan kualitas manajemen pembelajaran inovatif guru

\section{PENUTUP}

Berdasarkan analisis dan pembahasan seperti yang telah dipaparkan pada bagian sebelumnya, ditemukan beberapa hal sebagai berikut:

Pelaksanaan supervisi pembelajaran non-direktif sangat refresentatif dalam meningkatkan kemampuan guru menyajikan pembelajaran PAIKEM pada guru Agama Hindu Tingkat SD gugus KElusa Kecamatan Payangan Kabupaten Gi- anyar. Berdasarkan nilai rata-rata kemampuan guru terhadap 14 aspek yang dinilai terjadi peningkatan dari pra siklus ke siklus II sebesar 1,60, yaitu pada pra siklus rata-rata 1,54 pada siklus I meningkat menjadi 2,53 dan pada siklus II menjadi 3,14 dalam penilaian sklaa 1-5. Selain itu terjadi pula peningkatan kompetensi guru dalam menyusun skario pembelajaran yakni yang semula pada pra siklus dengan rata-rata 63,33 dalam kategori kurang, pada siklus I hasilnya 78, 83 termasuk katagori "cukup" dan pada siklus II mengalami peningkatan menjadi 84,17 atau dengan kategori amat Baik. Prosentase kemampuan guru dalam menyajikan pembelajaran PAIKEM juga mengalami peningkatan yang signifikan, yaitu sebesar $84 \%$ yaitu pada prasiklus mencapai $16 \%$ atau hanya 1 guru yang ada dalam kategori baik, siklus I $66 \%$ yaitu ada 4 orang guru yang berada dalam kategori baik serta pada siklus II prosentase mencapai $100 \%$ atau dengan kata lain semua guru yang menjadi subjek penelitian telah mampu menyusun pembelajaran PAIKEM.

Dengan demikian penelitian ini dicukupkan pada siklus II sebab secara konseptual indikator kerja penelitian telah tercapai. Secara umum tahapan-tahapan pelaksanaan supervisi pembelajaran non-direktif yang dilakukan sudah sesuai dengan rencana.

Berdasarkan kesimpulan dan implikasi penelitian yang telah dipaparkan di atas, maka dapat disarankan bahwa:

1) Model supervisi pembelajaran non-direktif dapat dijadikan salah satu alternatif pendekatan dalam melaksanakan supervisi pembelajaran;

2) Supervisi yang dilakukan harus mampu menciptakan hubungan kemanusiaan yang harmonis. Hubungan kemanusiaan yang diciptakan harus bersifat terbuka, berkesetiakawanan, informal, baik antara supervisor dengan guru maupun dengan pihak lain yang terkait. Oleh sebab itu, dalam pelaksanaan supervisor harus memiliki sifat-sifat, seperti: suka membantu, memahami, terbuka, jujur, ajeg, sabar, antusias, dan penuh humor;

3) Supervisi harus obyektif, artinya bahwa penyusunan program supervisi harus didasarkan kebutuhan nyata dalam pengembangan profesional guru. Di samping itu, dalam menentukan keberhasilan program supervisi, instrumen pengukurannya memiliki validitas 
dan reliabilitas tinggi, sehingga hasilnya dapat memotivasi guru dalam mengembangkan profesionalisme khususnya dalam mengembangkan manajemen pembelajaran inovatif.

4) Bagi Lembaga Pendidikan Tenaga Kependidikan (LPTK) yang mencetak calon guru agar memperkenalkan model pembelajaran berbasis masalah sejak dini kepada mahasiswa sehingga pada saat mereka menjadi guru, betul- betul paham cara menerapkan model pembelajaran pada proses pembelajaran. Selain itu, untuk pihak-pihak yang berwenang menangani bidang pendidikan, agar melatih terlebih dahulu guru-guru tentang model pembelajaran inovatif sebelum mereka diminta mengaplikasikan dalam pembelajaran. Dengan jalan demikian, diharapkan guru telah terbiasa menggunakan model pembelajaran inovatif dalam pembelajaran.

\section{DAFTAR PUSTAKA}

Adams, H.F. dan F.G. Dickey, 1959, Basic Principles of Supervision, New York.

Bafadal, Ibrahim, 1992, Supervisi Pengajaran Teori dan Aplikasinya dalam Membina Profesional Guru, Jakarta, Bumi Aksara

Briggs, T.H. dan J. Justman, 1954, Improving Instruction Through Sueprvision, New York, The Macmillan Company

Candra, 2008, "Analisis Hubungan Implementasi Supervisi Pengajaran Para Pengawas, Pengalam dalam Pelatihan dan Lingkungan Sekolah terhadap Kompetensi Profesional Guru IPA SMP Negeri di Kabupaten Badung" (tesis), Singaraja, Undiksha

Chrintenson, C., T.W. Johnson, dan J.E. Stinson, 1982, Supervising, California, Addison-Wesley Publishing Company.

Cogan, M.L. 1973, Clinical Supervision. Boston, Houghton Mifflin.

Daresh, J.C., 1989, Supervision as a Proactive Process. New York \& London, Longman

Depdikbud, 1998/1999, Supervisi, Pelatihan Manajemen Pendidikan bagi Kepala Sekolah Menengah Umum se-Indonesia di Surabaya, Jakarta, Depdikbud, Dirjen Pendidikan Dasar dan Menengah Direktorat Pendidikan Menengah Umum

Garman, N.B., 1982, “The Clinical Approach to supervision,” dalam Thomas J. Sergiovanni (ed), 1982, Supervision of Teaching, Alexandria, Association for Supervision and Curriculum Development.

Glickman, C. D., 1980, Development Supervision (Alternative Practice for Helping Teacher Improve Instruction). Virginia: ASCD.

Goldhammer, R., 1969, Clinical Supervision: Special Methods for the Suervision of Teachers. New York: Holt, Rinehart and Wiston.

Goldhammer, R., R. H. Anderson, dan R.A. Krajewski, 1981, Clinical Supervision: Special Methods for the Supervision of Teaching, Second Edition, New York, Holt, Rinehart, and Winston.

Gwynn, J.M., 1961, Theory and Practice of Supervision, New York: Dodd, Mead \& Company.

Koper, 2008, "Studi Korelasi Penilaian Guru tentang Perilaku Kepemimpinan Kepala Sekolah, Moral Kerja, dan Motivasi Kerja Guru dengan Kinerja Guru SD Inti di Kecamatan Mengwi Badung" (Tesis) Singaraja, Undiksha

Krajewski, R.A., 1982,"Clinical Supervision: A Conceptual Framework," Journal of Research and Development in Education. Volume 15, Athen, Georgia.

Mantja, W. 1984, "Efektivitas Supervisi Klinik dalam Pembimbingan Praktek Mengajar Mahasiswa IKIP Malang," Tesis, FPS IKIP Malang.

Mantja, W., 1989, "Supervisi Pengjaran Kasus Pembinaan Profesional Guru Sekolah Dasar Negeri Kelompok Budaya Etnik Madura di Kraton," Disertasi, FPS IKIP Malang.

Marks, S. J. R., E. Stoop, dan J.K Stoops, 1985, Handbook of Educational Supervision, Third Edition. 
Boston: Allyn and Bacon, Inc.

Mosher, J.T. dan D.E. Purpel, 1972, Supervision: The Reluctant Profession. Boston: Hoghton Mifflin Natajaya, N. 1994, "Studi hubungan antara Pelaksanaan Supervisi Pengajaran dengan Kemampuan Mengajar PMP Guru-Guru SD Negeri se-Kabupaten Buleleng di Daerah Tingkat II Buleleng" (Tesis). Malang: IKIP

Natajaya, N. 2003. "Profil Kepemimpinan Kepala Sekolah SLTP di Daerah Kabupaten Buleleng" (Hasil Penelitian). Singaraja: IKIP

Neagley, R.L. dan N.D. Evans, 1980, Handbook for Effective Supervision for Instruction, Third Edition, Englewood Cliffs, New Jersey, Presentice-Hall, Inc.

Olivia, P.F., 1984, Supervision for Today's School, Second Edition, White Plains, New York, Longman.

Ornstein, A.C. and H.L. Miller, 1980, Looking into Teaching: An Introduction to American Education. Chicago, Rand McNally College Publishing Company.

Peraturan Pemerintah Republik Indonesia Nomor 19 Tahun 2005 Tentang Standar Nasional Pendidikan, Jakarta, Depdiknas.

Sahertian, A. P., dan Ida Alieda, 1990, Supervisi Pendidikan dalam Rangka Program Inservice Education, Jakarta, Rineka Cipta.

Sahertian, P., 2000, Supervisi Pendidikan dalam Rangka Program Inservice Education. Jakarta: Rineka Cipta.

Sergiovanni, T.J. 1982. Editor. Supervision of Teaching. Alexandria: Association for Supervision and Curriculum Development.

Sergiovanni, T.J. 1987. The Principalship, A Reflective Practice Perspective. Boston: Allyn and Bacon.

Sergiovanni, T.J. dan R.J. Starrat. 1979. Supervision: Human Perspective. New York: McGraw-Hill Book Company.

Sergiovanni, T.J. et al. 1987, Educational Governance and Administration, Second Edition, Englewood Cliffs, NJ, Prentice-Hall, Inc.

Sri Wardhani, 2006, Model Pembelajaran Matematika dengan Pendekatan Berbasis Masalah, Jakarta, Depdiknas

Subari, 1988, Supervisi Pendidikan, Surabaya, Ikrar Mandiri Abadi.

Trianto, 2007, Model-model Pembelajaran Inovatif Berorientasi Konstruktivistik, Jakarta, Prestasi Pustaka.

Widarsana, 2008, "Analisis Gaya Kepemimpinan Kepala Sekolah, Kualitas Supervisi Pengawasan, dan Semangat Kerja Guru Terhadap Kualitas Pembelajaran Guru di Kabupaten Badung" (Tesis), Singaraja, Undiksha

Wiles, J. dan J. Bondi., 1986, Supervision: A Guide to Practice, Second Edition, Columbus, Charles E. Merrill Publishing Company.

Wiles, K., 1955, Supervision for Better Schools, New York, Prentice-Hall, Inc. 